\title{
A Comparative Analysis of Corporate Criminal Liability in Nigeria and Other Jurisdictions
}

\author{
Kingsley O. Mrabure ${ }^{*}$, Alfred Abhulimhen-Iyoha² \\ ${ }^{1}$ Faculty of Law, Delta State University, Abraka, Nigeria \\ ${ }^{2}$ Edo State Judiciary, High Court Complex, Benin, Nigeria \\ Email: *kingomote@yahoo.com, aaiyoha@yahoo.com
}

How to cite this paper: Mrabure, K. O., \& Abhulimhen-Iyoha, A. (2020). A Comparative Analysis of Corporate Criminal Liability in Nigeria and Other Jurisdictions. Beijing Law Review, 11, 429-443. https://doi.org/10.4236/blr.2020.112027

Received: March 4, 2020

Accepted: April 19, 2020

Published: April 22, 2020

Copyright $\odot 2020$ by author(s) and Scientific Research Publishing Inc. This work is licensed under the Creative Commons Attribution International License (CC BY 4.0).

http://creativecommons.org/licenses/by/4.0/ (c) (i) Open Access

\begin{abstract}
This paper attempts a comparative analysis of corporate criminal liability in Nigeria, the United Kingdom, the United States and India. Candidly, it is trite that the law clothes a company with personality such that its rights and duties are distinct from those of its members, because a company is a legitimate entity. Under common law, companies are responsible for criminal offences subject to certain exceptions such as robbery, kidnapping, murder and rape. No mental state was required in this regard and the punishment that was then practicable was a fine that could simply be levied on a corporation. Presently, in offences involving proof of mens rea, companies will effectively be held liable by imputing the state of mind of employees and the directors who are the alter ego and directing minds of the corporation. While this is the position in Nigeria, the United Kingdom and the United States. India, however, is not in pace with the developments as well as they do not make corporations criminally liable and if or when they do, no other punishment is imposed on them except fine. The paper concludes by stating unequivocally that Nigeria should hold on to the alter ego doctrine due to its clarity and predictability but it should infuse the aggregation theory (collective knowledge) developed in the United States because that makes it easier for the prosecution of companies as against the single lane approach (the alter ego doctrine) which requires that companies should take responsibility for the persons having decision making authority for the policy of the corporation rather than the persons implementing such policies.
\end{abstract}

\section{Keywords}

Corporate Criminal Liability, Alter Ego, Punishment, Respondeat Superior, Legal Responsibility 


\section{Introduction}

Corporate crimes are defined as illegal acts, omissions or commissions by corporate organizations, social or legal entities or by corporate officials or employees acting in accordance with the organization's operational objectives or standards, operating procedures and cultural norms, intended to benefit the corporations themselves (Lederman, 2001). In the same vein, corporate criminal liability may be defined as a crime committed by an individual or association of persons who for the purpose of pursuing a common purpose or making business gains in the course of their employment, commit such acts or omissions as prohibited by law and with a guilty mind where it is for the benefit of the corporation or of any other person, individual or association of individuals (Legal service India).

Furthermore, corporate criminal liability is the liability imposed upon a corporation for any criminal act done by any natural person (United States legal) while corporate liability employees are the legal responsibility of a corporation for criminal actions. If the actions done for the benefit of the company are as a result of negligence or if they occurred due to lack of responsible management by the company, the corporation can be persecuted and punished (Business dictionary).

Candidly, it is trite that the law clothes a company with personality such that its rights and duties are distinct from that of its members. This was judicially applied for the first time by the House of Lord in the case of Salomon v Salomon and Co Ltd. (1897).

Mid way through the 19th century, corporate criminal liability was extended to all offences committed by the company which did not require evidence of criminal intent in the field of criminal law. Corporate personality and corporate criminal liability regulation have given rise to significant controversy. "No one grew it, no one cultivated it, no one rooted it, it was just growing" (Mueller, 1957). It was doubtful in the past that a corporation might be held liable (Emem \& Uche, 2012). The point generally advanced was that a corporation as an artificial person has no physical existence and could therefore not be subjected to the prescribed penalties attached to offences (Reasons, 1991; Amao, 2008). In other words, Smith and Hogan (2002) aptly put it thus: "Since a corporation is a creature of law, it can only do such acts as it is legally empowered to do, so that any crime is necessarily ultra vires and the corporation having neither body nor mind, cannot perform the acts or form the intent which are prerequisite of criminal liability."

Under common law, companies are criminally liable subject to certain limits, such as assault, robbery, murder and rape. This position allows a corporation to be held criminally liable for acts of non-feasance in common law and this was later extended to cover only misfeasance. In this respect, no mental state was needed and the punishment that was then practicable was a fine that could easily be paid by a company (Slapper, 2010). 
In R v African Press (1957), a corporation was found guilty of an offence of contravening section 51 (1) (c) of the Nigeria's criminal code. Similarly, in Mandilas \& Karaberis v. COP (1958), a corporation was convicted of the offence of stealing by conversion under sections 390 and 383 of the Nigerian criminal code. While in A.G Eastern Region v. Amalgamated Press of Nigeria Ltd. (1956-57), the preliminary objection raised by the defence counsel on the ground that an offence could not be committed by a corporation in the absence of mens rea was overruled by the court.

Today, companies are easily held accountable in cases involving the proof of mens rea by imputing the state of mind of, for example, the directors who are the alter ego and directing mind of the corporation.

Therefore, in the view of the above, this paper attempts a comparative analysis of corporate criminal liability by looking at the concept, the models, the laws and case law in Nigeria and other jurisdictions such as the United States of America, United Kingdom and India respectively.

\section{Literature Review}

Laufer argues that regulation of corporate bodies has traditionally been ineffective and that changes aimed at such supervision would continue to fail if there is no consensus between academic and criminal law to achieve the desired outcome (Laufer, 2007). As regards the degree of criminal punishment on corporations, Lott Jr posited that criminal proceedings involving corporations as a definite entity requires higher level of proof than would attain in civil proceedings but that the ultimate penalty is conviction to pay fine and not imprisonment (Lott Jr., 1996).

In their view, Florin and Chirita claim that a corporation has the mental capacity to perform a crime that requires mental blame, because if the ability of the corporation to act and determine is known in contract, administrative and constitutional laws and if the corporation has the capacity to think and decide when it is a party to the contract (and if it is a party to the contract). They conclude, and, rightly too, that the blameworthiness of corporations exists and it is sufficient for the culpableness required by the criminal law (Florin \& Chirita 2002).

It remains that where corporate criminal liability is in issue, those liable may include the company itself, board members and corporate officers. With respect to how corporate criminal liability could be imputed to companies, Chinyere maintained that the situations under which corporate criminal liability could be imputed to businesses include occasions where an employee acted within the scope and nature of his employment or the employee acted at least in part to benefit the corporation, or intent is imputed to the corporation or, where the criminal act is the policy of the corporation's internal decision-making procedures, or where such an act is encouraged to be committed by the corporation. On the issue, however, of whether the company should be held criminally liable in all respects for the conduct of individual employees. She holds that the com- 
pany shall be responsible unless it is shown that the corporation has done everything in its power to prevent such misconduct (Chinyere, 2009).

Stessens' opinion is that nowadays a significant part of the crime takes place by businesses that compels the legal system to intervene in prosecuting corporations. He believes that strong punitive sanctions against companies are the only effective way to combat corporate. To prosecute individual workers only is not simply unfair, it is ineffective too. He examines the question of how to punish corporate criminality in comparative perspectives. He compares the national law system of some countries, like USA, France, the Netherlands, Germany, Canada, England and Wales. This comparison helps to bring out a clearer view of the advantages and disadvantages of corporate criminal liability. He further maintained that the only effective way to combat corporate crime is to direct punitive sanctions against corporations (Stessens, 1994).

Ali in his book, Corporate Criminal Liability in Nigeria has made outstanding contributions in the field of corporate criminal liability. He identifies three theories that could be held criminally accountable by companies, namely: The Respondent superior, Vicarious liability, and the Doctrine of Alter Ego. He explores the corporate organizational and administrative systems in examining these hypotheses with a view to finding out that companies can also commit business crimes. In following the fundamental concepts of first held liable, for civil wrong and, second, for criminal act. He acknowledges the fact that without some challenges, none of the frameworks or grounds of criminal liability built up to now have full and sufficient criteria for liability. The author argues that no precise legal framework for predicating corporate criminal liability has emerged. He asks the question, "should we need to find out guilty mind at the directorial level, or should we simply judge the company by the outcome of its conduct?" The learned author maintains that it is now clearly settled that the legislature and the courts have come to recognize corporate criminal liability (Ali, 2008).

Glanville Williams in his book, Textbook of Criminal Law stipulates that an organization or corporation is a separate legal entity from the individual entities that form its structure and is attributably responsible to its workers to the degree that it is a human employer. The learned author goes further to assert that the business or company is additionally identified with its controlling officers, whose acts and state of mind are imputed to it. He contends that in the case of a trading company; the controllers are the directors and other person(s) (such as the manager or secretary) to who they delegate wide discretion to act on their behalf. But a branch manager who is highly controlled by a higher officer is not himself a controller. He argues that the corporation is branded with its manager after engaging in the company's theft, but it seems clear that the recognition will only take effect in relation to actions committed on the company's business fraud of the company (Williams, 1983).

It is submitted that corporate bodies are now held criminally liable both under the common law, or codes and statutes. We state that in many instances, where they have been held liable, they were fined even when there is provision for a jail 
term. This stand conflicts with the principles which a natural person with corresponding powers, benefits and liabilities possesses.

\section{Theories of Corporate Criminal Liability}

Corporate criminal liability started by imitating criminal liability. There have been models and theories of criminal liability that have been developed to fit and better the structure of the corporation. The American system of corporate criminal liability has been the most developed system so far. Most of the theories of corporate criminal liability are typical of common law developments, which were put on a case by case basis. These theories however, have proved to be ineffective, for lack of strong basis or their individualistic roots.

\subsection{Agency Theory (Vicarious Liability)}

This theory was first developed in torts law and gradually carried over into the criminal aspect. Here, the corporation is liable for the acts and intents of its employees (Legal service, India). Vicarious liability is based on the principle of Respondeat Superior which means let the master answer. It is a general rule of torts where the employer can be held liable for all acts of the employees done during the course of employment. Vicarious liability is commonly employed in the United States. In other jurisdictions, the theory is established in relation to strict liability and hybrid offences, but not mens rea offences.

The Agency Theory is based on the fact that criminal violations entail two elements; actus reus and mens rea; the act and the intent. Since a corporation is an incorporeal legal entity, the only way to impute intent is by considering the state of mind of the employees. Whoever has the intention in the company is part of the corporation, and therefore the intention of the employee is also the intention of the corporation.

To determine whether the corporation will be held vicariously liable for the acts of the employees, the employee must first be acting within the scope of his employment. In the case of New York Central Railroad Co. v. United States (1909), the corporation was convicted of violating the Elkins Act where a general and an assistant traffic manager paid rebates for shipment of sugar. The agents were operating within the real authority system because they were allowed to set freight rates. Therefore, they acted within the scope of authority the organization put on them. Even the actions of non-employees can be viewed as the conduct of the company.

In United States v. Parfait Powder Puff Co (1947), it was held that independent contractors must operate for the corporation's benefit and thus subject it to criminal liability. The agents acted within the scope of actual authority because they were authorized to set up freight rates. Therefore, they acted within the scope of authority conferred upon them by the corporation. Even non-employees conduct can be attributed to be as the corporation's action. In United States V. Parfait Powder Puff Co (1947), it was held that independent contractors might 
act for the benefit of the corporation thereby exposing it to criminal liability.

Secondly, the employee must be acting, at least in part, for the benefit of the company, though it is quite irrelevant whether the company actually receives the benefit or whether the act was expressly prohibited. It is not necessary for the employee to be concerned primarily with the benefit of the company, since many employees are primarily concerned with their own personal gain (United States v. Bainbridge Management, 2002).

The third factor is that the act and intent must also be imputed to the corporation (United States v. One Parcel of Land, 1992).

\subsection{Identification Theory (Attribution or Alter Ego)}

This theory is a more traditional method in which companies are held liable in most countries virtue of the common law, which led to the construction of a direct liability theory. The theory requires that companies should take responsibility for the persons having decision making authority for the policy of the corporation rather than the persons implementing such policies. It focuses on the directing minds of the company and the fact that the intention and action of the company are the results of the employees of the company. The doctrine is also called Doctrine of Attribution or Alter-Ego.

In Lennard's Carrying Co Ltd v Asiatic Petroleum Co. Ltd. (1915), Viscount Haldene fashioned a mode of primary corporate criminal liability for offences that require mens rea that was later known as identification theory. The main principle of the theory is the identification of the guilty mind. A good instance is the case of Tesco Supermarket v. Nastrass (1972), where the acknowledgement of the individual became known as the corporation itself and who will be the very ego or personality of the company. A company is linked to a human body and it has a brain that controls what it does. The board of directors of the company, its Managing Directors and other superior officers who carry out the management and control the will and the mind of the company. Some jurisdictions like the US and Australia have constantly applied this principle. Canada has taken a broader approach to include "everyone who has an important role in setting policy or managing an important part of the organization's activities under the category of officers". This would also include the management with operational and policy making authority. This doctrine is also incorporated in Nigeria.

\subsection{Aggregation Theory (Collective Knowledge)}

This theory was first developed in torts law and gradually carried over into the criminal aspect. Here, the corporation aggregates the composite knowledge of different officers in order to determine liability. The company totals all the acts and mental elements of the important persons within the company to establish whether they would amount to a crime if they had all been committed by one person. The theory of aggregation is a result of the doings of American Federal 
Courts. The leading case here is United States v. Bank of New England (1987), where the court stated that corporations compartmentalize knowledge, subdividing the elements of specific duties and operations into smaller components.

The set of those items reflects the knowledge of the organization about a particular transaction.

It is meaningless whether employees who administer one part of an activity learn about the specific activities of employees who administer another aspect of the operation. The theory appears to be similar to respondeat superior (vicarious liability) principle of presumed or deemed knowledge. The aggregate knowledge and the acts of several officers that satisfy the elements of the criminal offence even if no employee or agent has the necessary knowledge to fulfill the statutory requirement to be guilty of a criminal offence. The American courts have been cautious in applying this decision because they recognize that a company could not be considered guilty when a single employee does not hold that state of mind.

\section{Corporate Criminal Liability in Nigeria}

The Nigerian legal system fits the same structure as the English legal system and is in keeping with the common law stance that corporations could be held liable legally, but not for all offences. In Nigeria, the emphasis in assessing corporate criminal liability is on the alter ego concept, which is the method embraced to evaluating actual intentions and corporate mens rea.

This is in line with the UK position and is consistent with the umbilical relation between Nigeria's legal system and British jurisprudence (Yusuf, 2017).

In Orji Uzor Kalu v FRN (2012), the Court of Appeal made that conclusion when asked to determine corporate criminal liability by stating that the defendant, who was the first to be convicted in the case before the Federal High Court, was the alter ego of the second accused Slok Nigeria Limited and remained his driving spirit even while he was the Governor of a State. Another panel of the Court of Appeal in Romrig Nigeria Limited V FRN (2017) followed the same route, where it ruled that another accused person who is a director of Romrig Nigeria, was its alter ego and his absence at a key meeting with the Prosecutor meant that the company was not part of the agreed outcomes at the plea bargain meeting.

Corporate personality was established in Nigeria and evidence of this is given under the Companies and Allied Matters Act (CAMA) (2004) virtue of section 37 of CAMA which states that:

As from the date of incorporation mentioned in the certificate of incorporation, the subscriber of the memorandum together with such other persons as may, from time to time become members of the company, shall be a body corporate by the name contained in the memorandum, capable forthwith of exercising all the powers and functions of an incorporated company including the power to hold hand, and having perpetual succession and a common seal, but 
with such liability on the part of the members to contribute to the assets of the company in the event of its being wound up as mentioned in this Act.

In Nigeria, corporate criminal liability is a recent development and cases are quite few. However, in Ogbuagu v. Police (1953), the appellant was the proprietor and publisher of a Newspaper in Jos, Northern Nigeria. When leaving Jos, he instructed the man he left in charge not to publish the paper while he was away. The man, however, published the paper which contained a seditious libel in one issue. In allowing the appeal against conviction by the lower court, the Appeal Court stated that; "when the proprietor tells the servant not to publish the paper, I cannot see why the proprietor should be answerable for an issue of a paper published by a disobedient servant". Here, the court refused to impute the state of mind of the employee to the proprietor of the newspaper.

However, in $R$. V. African Press (1957), a case with similar facts as Ogbuagu, the article was written by and under the responsibility of the editor and the court held both the defendant company and the editor jointly liable since the article was written by and under the responsibility of the editor.

In Inspector General of Police v Mandilas and Karaberis and Anor (1958), the court jointly held liable the company and its manager for the offence of stealing. In his judgement, Thomas J. found on the general principle that a company operates through its agents and that once those agents act within the limits of their employment, the owner, who is the corporation, would be responsible in a vicarious and fraudulent way. Wherever a statute defines an obligation in such a manner that a violation of the duty amounts to a disobedience of the law, then where there is nothing in the statute either explicitly or indirectly to the contrary, an infringement of the legislation is an offence for which a corporation may be sued, whether the statute applies to corporations or not. In his judgment, Thomas J. relied on the general principle that a corporation acts through its agents and that once such agents act within the scope of their employment, the principal, which is the corporation would be vicariously and criminally liable.

Wherever, a duty is imposed by statute in such a way that a breach of the duty amounts to a disobedience of the law, then if there is nothing in the statute either expressly or impliedly to the contrary, a breach of the statute is an offence for which a corporation may be indicted, whether or not the statute refers in terms to corporations. In $R v$ Tyler and International Commercial Company Ltd. (1891), Bowen L. J. stated that the Interpretation Act of 1889, an English statute provides that: "in the construction of any enactment relating to an offence punishable on indictment or on summary conviction, the expression 'person' unless the contrary intention appears, includes a body corporate". This principle is also applicable in Nigeria. Certain statutes provide that where a corporation has committed an offence, its officials shall in certain circumstances be deemed guilty of that offence.

In respect of the above, Okonkwo explained the concept of legal personality as it applies to criminal law in Nigeria and in particular its applicability to corporate criminal liability. In his evaluation, the criminal code, the law regulating of- 
fences in Nigeria does not provide for any special provisions on corporate criminal liability (as distinct from the individual liability of members comprising the company) and this to him cast doubt on the applicability of the concept. He further stated that there is no "special reason why in principle a corporation should not be committed under the criminal code". He concludes that every offence in the code starts with "any person...." and it is trite law that a company is a "person" (Okonkwo \& Naish, 1980).

In Nigeria, there has been a growing trend to subject companies to severe punishments outside the punishments prescribed for individuals who may have acted on the company's stead and statutes have been specifically enacted in addition to Nigerian criminal code and penal code which have provisions for corporate criminal liability. Such statutes include the Food and Drug Act, Standard Organization of Nigeria Act, the Companies and Allied Matters Act, the Consumer Protection Council Decree (2004) and a host of other statutes.

A law that serves as a good illustration of a deliberate focus to hold companies criminally liable for acts of their employees, managers and directors is the Failed Bank (Recovery of Debts) and Financial Malpractices Act (2004). The Act seeks to instill sanity into the banking industry by making it punishable for the bank or any financial institution and any of its staff who contributes in any manner to the collapse of the financial institutions. A case that was decided under this provision, was the Federal Republic of Nigeria v. Dr. Nwochie Odogwu and Capital Merchant Bank No.1 (1997). In this case, the managing director of Capital Merchant Bank was also the promoter of the Bank in its formative stage. He floated other sham companies to which he granted unsecured loans which he later diverted to his personal purse. Within a short time, the bank went into liquidation and all the depositors lost their money. Both the bank and its managing director were charged before the Failed Bank Tribunal. The managing director was sentenced to 18 years jail term and ordered to refund \#76 million naira, with a fine of $\# 35,000.00$ while the bank itself was discharged and acquitted. It would seem from this judgement that the tribunal simply lifted the veil of incorporation to find out who was behind the mask. It accordingly dealt with the natural person behind the mask instead of chasing the ghost by holding the bank criminally liable for an act that was masterminded by its employee for his own benefit. This kind of judgment, although is in the best interest of the public seems to have done away with the principle of distinct corporate entity (Salomon v Salomon and Co. Ltd., 1897).

As far as Companies and Allied Matters Act under section 65 is concerned, any act of the members in a general meeting, the Board of Directors, or of managing director shall be treated as the act of the company. Also, the acts of officers or agents will not be deemed to be acts of the company unless the company through the members in the general meeting, board of directors or managing director expressly or impliedly authorized the agent to act in the matter or the company represented the officer or agent, in which event the company shall be civilly liable. The Companies and Allied Matters Act does not provide any se- 
rious statutory solution or remedy against a company for corporate crimes committed against public interest.

There is no doubt that under both statutory and case law in Nigeria, criminal intent of companies has been established and hinged on the direction set by the English common law through the attribution principles.

\section{Corporate Criminal Liability in Other Jurisdictions}

This will be discussed in other jurisdictions such as United States, United Kingdom and India.

\subsection{United States of America}

Corporations were not held criminally liable for corporate activities as a corporation was considered a fictitious legal entity and cannot form the necessary mens rea to commit a crime. This belief was squashed by the Supreme Court in 1909 in the case of New York Central and Hudson River Railroad v. United States (1908) where it clearly held that a corporation is liable for crimes of intent. The case imported the doctrine of respondeat superior from torts law into criminal law (Yadav, 2015). United States law both at the State and Federal levels provide for criminal liability for corporation of crimes committed by individual directors, managers, or low-level employees (Beale, 2004).

The Model Penal Code, 1962, lays down an added qualification. According to the code, the execution of the offence should be approved, demanded, directed, carried out or accepted in a reckless manner by the board of directors or a senior manager working on behalf of the company within the limits of his office. Thus, the code distinguishes between the ability of the managerial employees and the lower level employees to prevent a corporate crime.

The United States sentencing commission refused to promulgate corporate fine standards for other offences, leaving such fines to the general statutory sentencing provisions. The sentencing court however, has the discretion in applying fines and may take into account a variety of factors, including the presence of an effective ethics and compliance program. A corporation may be punished by fine or their property can be confiscated which can be levied by the orders of the court. There is no minimum amount under the statute but the statute provides maximum amounts for different kinds of offences committed by organizations. Corporations can also be placed on probation or ordered to pay restitution. Depending on the specific statute, other sanctions can be instituted, such as suspension or debarment from entering into contracts with the Federal government (Linklaters).

\subsection{United Kingdom}

For many decades, companies have been criminally liable for wrongdoing in the U.K. A corporation is not indictable, but the members of the company are. A corporation is civilly and criminally liable for the acts of persons authorized to 
and have acted in a particular manner out of which the unlawful act has resulted. The courts in England have emphatically rejected the notion that a body corporate could not commit a criminal offence which was an outcome of an act of will needing a particular state of mind. In the case of Director of Public Prosecutors v. Kent and Sussex Contractors Ltd. (1994), Macnaghten J stated that: “A body corporate is a person to whom there should be imputed the attribute of a mind capable of knowing and forming an intention. A body corporate can have the intent but not criminal intent". It can only know or form an intention through its human agents, but circumstances may be such that the knowledge of the agent must be imputed to the body corporate.

The case of Mousell Bros Ltd v London Northwestern Ry Co. (1917), was the first case in UK in which corporate liability was moved beyond the confines of strict liability or nuisance. Also, in the case of Tesco Supermarket v. Nastrass (1972), Lord Reid held that in order for liability to attach to the actions of a person, it must be the case that "the person who acts is not speaking or acting for the company. He is acting as the company and his mind which directs his acts, is the mind of the company. If it is a guilty mind, then that guilt is the guilt of the company".

In order to remove the difficulty of imputing criminal liability on corporations, the UK has come up with two significant corporate offences and legislations addressing them. These are corporate manslaughter and failure to prevent bribery. A corporation can be held liable under both vicarious and non-vicarious liability. The offence of bribery under the Bribery Act 2010 falls under vicarious liability. The Tesco's case ratio is still the prevailing law of corporate criminal liability in the UK.

The sanctions imposed on companies are generally of two sorts: imprisonment (up to a certain number of years) and an unlimited fine. Even though, a company cannot be imprisoned, if individuals are separately convicted in relation to the same activity, they may be. In the event of a corporate conviction, the court will most likely impose a fine. Sentencing courts take into account guilty plea when assessing fines. A company that has pleaded guilty to the offence charged or to some lesser offence can expect to receive a lower fine than if it had fought the case unsuccessfully. The degree of discount depends on the stage at which the guilty plea is entered (Linklaters, 2016).

\subsection{India}

Companies in India are regulated and governed by the provisions of the Companies Act 2013. Certain provisions of the Act hold only the individuals liable and not the company itself. Until the concept of corporate criminal liability was established, courts in India did not punish corporations as they felt that the important ingredient, mens rea is absent especially since a company is a fictitious legal being that has no physical existence and cannot be charged for any criminal offence. However, due to so many difficulties, which was noticed by the Law 
Commission in its $41^{\text {st }}$ report of Law Commission of India where the amendment was suggested in section 72 (1) (a) of the Indian penal code to include fine as an alternate punishment in cases involving corporations, but the bill lapsed and the view of the Courts regarding the concept of corporate criminal liability changed in the recent groundbreaking judgement in 2005 of the Apex Court in the case of Standard Chartered Banks and Ors v Directorate of Enforcement and Ors (2005), that overruled all previous views.

The above case was related to the now defunct Foreign Exchange Regulation Act (1973), otherwise known as FERA. The majority held that the company is not immune from prosecution merely because the prosecution is compulsory imprisonment in relation to offences for which the punishment prescribed is. Since the company can't be sentenced to jail, the Court can't impose the penalty, but when incarceration and fine are the required punishment, the Court should impose the fine that should be imposed on the company. Such a right is to be read in Foreign Exchange Control Act and Ss section 56.276-C and 278-B of the Income-Tax Act (1961) in respect of a legal person. Of example, as with a human being, the Court cannot exercise the same discretion. As far as business is concerned, the Court can always enforce a penalty of fine and the punishment of incarceration can be dismissed as it is impossible to execute in regard to a company. It cannot be said that any company has a blanket immunity from any prosecution for serious offences simply because the prosecution would ultimately involve a sentence of mandatory imprisonment. The 3:2 majority bench held that a corporation could be punished and is criminally liable for offences for which both imprisonment and fine are mandatory punishments. Even when the company is found guilty, the jail sentence cannot be imposed on the company and then the penalty sentence is to be imposed and the judge has the judicial discretion to do so. This path is available only if the corporation is found guilty, but if a human citizen is found guilty in this manner, both the jail penalty and the fine must be levied on that person.

This particular judgment has further crystallized the Court's interpretative power with regards to a penal statute, by departing from the traditional view and endorsing that for the punishment of the crime, the court should go beyond the strict word and not let offences go unpunished due to application of too technical an interpretation that is restrictive, strict and constricting to the very intent of the statute.

\section{Comparative Analysis}

In spite of the advantages and clarity of the alter ego doctrine approach adopted in the UK and Nigeria, it has some disadvantages. Some scholars are worried that the requirement that for companies to be criminally liable, the crimes must have been committed by a high ranking officer or manager constitutes an impediment in combating corporate crimes because most companies will avoid liability by empowering lower level employees to make decisions or act on its behalf. 
The UK system presents another disadvantage when requiring the identification of the individual who committed the act as a prelude to determine corporate criminal liability. The identification of the individual who committed the crime is often times impossible. Although, the alter ego doctrine has the advantages of being clear, predictable, and consistent with the general principles of criminal law, it still leaves a gaping hole in matters of general fairness and efficiency.

The US approach via the respondeat superior establishes a wide system of corporate criminal liability that promotes general fairness and deterrence but lacks the focus on clarity and precision associated with the alter ego doctrine. The US doctrine's adoption of the aggregation theory and the fact that any employee can engage the criminal liability of corporations has the advantage of making it easier for the prosecution of companies as against the single lane approach of the alter ego doctrine.

Corporate criminal law is gaining more importance in countries around the world, unlike before where it was believed that a corporation should not and cannot be held liable for any crime committed by a company. Now, courts have ruled that corporations have mens rea which is very essential to the commission of a crime. While that is the position in Nigeria, England and United States,. India, however, is not in pace with the developments as well as they do not make corporations criminally liable, and if or when they do, no other punishment is imposed on them except fine.

\section{Conclusion}

Therefore, in view of the above, first, we recommend that while Nigeria holds on to the doctrine of identification, due to the clarity and predictability, it should infuse the aggregation theory developed in the United States because that makes it easier for the prosecution of companies as against the single lane approach of the alter ego doctrine. Second, the criminal and penal code should have a clear law in place for corporate criminal liability. While, persons: in the criminal code should be expressly stated to include companies, as this has not been interpreted clearly.

\section{Conflicts of Interest}

The authors declare no conflicts of interest regarding the publication of this paper.

\section{References}

A.G. Eastern Region v Amalgamated Press of Nigeria Ltd. (1956-57). 1 E.R.N.R 18.

Ali, L. (2008). Corporate Criminal Liability in Nigeria (p. 181). Lagos: Malthouse Press Limited.

Amao, O. O. (2008). Corporate Social Responsibility, Multinational Corporations and the Law in Nigeria: Controlling the Multinational in Host States. Journal of African Law, 52, 89-113. https://doi.org/10.1017/S0021855308000041

Beale, S. (2004). A Response to the Critics of Corporate Criminal Liability. Criminal Law Review, 8, 89-90. https://doi.org/10.1525/nclr.2004.8.1.89 
Chinyere, C. (2009). Corporate Liability for Crimes. AJBPCL, 1, 46.

Company and Allied Matters Act (CAMA) (2004). Cap. C 20 Vol. 3 LFN.

Director of Public Prosecutors v. Kent and Sussex Contractors Ltd. (1994). 1 All ER 119.

Emem, C. E., \& Uche, P. (2012). A New Dawn of Corporate Criminal Liability Law in the United Kingdom: Lessons for Nigeria. African Journal of Law and Criminology, 2, 86-98.

Federal Republic of Nigeria v. Dr. Nwochie Odogwu and Capital Merchant Bank No. 1 (1997). 1 FBTLR 179.

Florin, S., \& Chirita, R. (2002). Raspunderea Penala a Persoanci Juridice (ed., 7 Rosetti) 34, Citing Wells C, Corporations and Criminal Responsibility (p. 96). Oxford: Clarendon Press.

Foreign Exchange Regulation Act 46 of 1973.

Inspector General of Police v Mandilas and Karaberis and Anor (1958). W.R.N.L.R.147.

Laufer, S. (2007). Corporate Bodies and Guilty Minds, the Failure of Corporate Criminal Liability. University of Chicago Journal, 1, 29-32. https://doi.org/10.7208/chicago/9780226470429.001.0001

Lederman, E. (2001). Models for Imposing Corporate Criminal Liability: From Adaptation and Imitation towards Aggregation and Search for Self-Identity. Buffalo Criminal Law Review, 4, 661-666. https://doi.org/10.1525/nclr.2000.4.1.641

Lennard's Carrying Co. Ltd. v Asiatic Petroleum Co. Ltd. (1915). 19 AC 705.

Linklaters (2016). Linklaters Corporate Criminal Liability: A Review of Law and Practice across the Globe.

Lott Jr., J. (1996). Corporate Criminal Liability. Journal of Business, 69, 339.

Mousell Bros Ltd v London Northwestern Ry Co. (1917). 2 KB 836.

Mueller, G. O. W. (1957). MENS Rea and Corporation. University of Pittsburgh Law Review, 19, 38-40.

New York Central and Hudson River Railroad v. United States (1908). 53 L ed.; 613: 212 U.S. 481.

New York Central Railroad Co. v. United States (1909). 212 U.S. 481.

Ogbuagu v. Police (1953). 30 NLR 139.

Okonkwo, C. O., \& Naish, M. E. (1980). Criminal Law in Nigeria (2nd ed., p. 379). London: Sweet and Maxwell.

Orji Uzor Kalu v FRN (2012). SC 215.

R v Tyler and International Commercial Company Ltd. (1891). 2 Q.B. 588 at 592.

R. V. African Press (1957). W.R.N.L.R. 1.

R. V. African Press (1957). WNLR 1.

Reasons, C. E. (1991). Crime against the Environment: Some Theoretical and Practical Concerns. Criminal Law Quarterly, 34, 86-92.

Romrig Nigeria Limited v FRN (2017). LOR 15/12/2017.

Salomon v Salomon and Co. Ltd. (1897). AC 22 at 51.

Slapper, G. (2010). Corporate Punishment. Journal of Criminal Law, 73, 181-184. https://doi.org/10.1350/jcla.2010.74.3.629

Smith, J. C., \& Hogan, B. (2002). Criminal Law: Cases and Materials (8th ed.). London: Butterworths.

Standard Chartered Banks and Ors v Directorate of Enforcement and Ors (2005). AIR 
2005 SC 2622.

Stessens, G. (1994). Corporate Criminal Liability, a Comparative Perspective. International and Comparative Law Quarterly, 43, 495-519.

https://doi.org/10.1093/iclqaj/43.3.493

Tesco Supermarket v. Nastrass (1972). 2 WLR 1166.

The Consumer Protection Council Decree (2004). Decree No. 66 of 1992. Now Cap C 25 Vol. 4 LFN.

The Failed Bank (Recovery of Debts) and Financial Malpractices Act (2004). Cap F 2 Vol. 6 LFN.

United States v. Bainbridge Management (2002). U.S. Dist. Lexis 16686 at 15 N.D. III Sept. 5.

United States v. Bank of New England (1987). 821 F. 2nd 844 (1st Cir.), Cert. Denied, 484 U.S. 943.

United States v. One Parcel of Land (1992). 965 F. 2D 311, 316 (7th Cir. 1992).

United States v. Parfait Powder Puff Co. (1947). 163 F. $2 D$ 1008, 1009-1010 (7th Cir. 1947).

Williams, G. (1983). Criminal Law (2nd ed., p. 1519). London: Stevens \& Sons.

Yadav, V. S. (2015). Corporate Criminal Liability: A Comparative Analysis of Judicial Trend. International Journal of Applied Research, 1, 756-760.

Yusuf, M. S. (2017). Criminal Liability of Corporate Persons in Nigeria. International Journal of Law, 3, 32-38. 